\title{
Using Zoom in Distance Learning on Currency Fraction Equivalence Materials
}

\section{Tri Yanti}

SD Negeri Bukateja 01

triyanti31@gmail.com

\section{Article History \\ accepted 14/11/2020}

approved $21 / 11 / 2020$ published 26/11/2020

\begin{abstract}
Since the announcement of a positive case of Covid-19, various efforts have been made by the government to prevent its spread. One of them is by implementing distance learning at all levels of education, including elementary schools. Even various distance learning media that used to be foreign to our ears are now getting closer. Every media that we use has advantages and disadvantages, Of the many distance learning media, the writer is interested in choosing zoom as a learning medium. The aim is to measure the effective use of zoom in mathematics learning on currency equivalence material. The author uses observational research methods to obtain valid data. Before learning by using zoom, the success rate is $20 \%$. After doing the research, the writer gets the result that the success rate of learning using zoom is $100 \%$. From the research results, it can be concluded that the use of zoom in distance learning is effective on the equivalent of currency fractions.
\end{abstract}

Key words: PJJ, zoom, currency denominations

\begin{abstract}
Abstrak
Sejak diumumkannya kasus positif covid-19 maka berbagai upaya dilakukan pemerintah dalam mencegah penyebarannya. Salah satunya adalah dengan menerapkan pembelajaran jarak jauh pada semua jenjang pendidikan tidak terkecuali sekolah dasar. Berbagai media pembelajaran jarak jauh pun yang dulu asing di telinga kita kini semakin akrab. Setiap media yang kita gunakan mempunyai kelebihan dan kekurangan, Dari sekian banyaknya media pembelajaran jarak jauh penulis tertarik untuk memilih zoom sebagai media pembelajaran. Tujuannya adalah untuk mengukur sejauh mana efektifnya penggunaan zoom dalam pembelajaran matematika pada materi kesetaraan mata uang. Penulis menggunakan metode penelitian observasi untuk mendapatkan data yang valid. Sebelum pembelajaran dengan menggunakan zoom tingkat keberhasilannya adalah $20 \%$ Setelah daidakan penelitian penulis memperoleh hasil tingkat keberhasilan pembelajaran dengan menggunakan zoom adalah 100\%. Dari hasil penelitian maka dapat disimpulkan bahwa penggunaan zoom dalam pembelajaran jarak jauh efektif pada materi kesetaraan pecahan mata uang.
\end{abstract}

Kata kunci: PJJ, zoom, pecahan mata uang

Social, Humanities, and Education Studies (SHEs): Conference Series https://jurnal.uns.ac.id/shes

p-ISSN 2620-9284

e-ISSN 2620-9292 


\section{PENDAHULUAN}

Di tengah masa Pandemi Covid-19 ini kebijakan pemerintahan memberlakukan belajar dari rumah yaitu pembelajaran secara daring. Secara tiba-tiba pembelajaran di sekolah yang semula yang sifatnya tatap muka berubah menjadi pembelajaran secara daring. Hal ini membuat semua dari tenaga pendidik harus mengikuti kebijakan dari pemerintah untuk belajar mengajar secara daring.

Banyak media yang bisa digunakan untuk pembelajaran jarak jauh bisa menggunakan WA Grup, Google Classrom, Google Sites, Sway, menggunakan website atau blog. Ada juga media yang digunakan adalah media tele conference seperti zoom, google meet, office 365, dan lain sebagainya.

Di tengah masa pandemic seperti sekarang ini pembelajaran jarak jauh yang dilakukan oleh guur tentu harus mempertimbangkan banyak hal. Selain kesesuaian materi dengan media yang digunakan, guru juga harus mempertimbangkan kemampuan guru dan siswa dalam mengakses media yang digunakan. Faktor lain yang tidak kalah pentingnya adalah bagaimana agar pembelajaran daring tidak terkesan garing.

Pembelajaran menentukan persamaan pecahan mata uang pada kelas II SD bukanlah pelajaran yang mudah apalagi jika disampaikan secara daring. Siswa perlu dibimbing langsung atau diberikan contoh secara nyata agar siswa mampu mengenal nilai mata uang dan juga mampu menentukan persamaan pecahan mata uang.

Dengan cara yang paling sederhana sebenarnya penulis bisa saja menggunakan media WA Grup untuk pembelajaran materi tersebut, namun hakikat belajar tidak dapat dicapai dengan menggunakan media WA Grup. Menurut Oemar Hamalik (2004: 27) " belajar adalah modifikasi atau memperteguh kelakuan melalui pengalaman (learning is defined as the modification or strengthening of behavior through experiencing)" . Menurut Bruner (dalam Ratna Wilis Dahar, 2011: 77), belajar melibatkan tiga proses yang berlangsung bersamaan yaitu: Memperoleh informasi baru; Transformasi informasi; Menguji relevansi dan ketepatan pengetahuan.

Jika kita mengacu pada pendapat ahli di atas maka dapat kita pahami bersama bahwa ketiga proses belajar yang berlangsung bersamaan sulit untuk kita wujudkan dengan pembelajaran menggunakan WA Grup. Tentu saja cara yang paling efektif adalah dengan menggunakan metode tatap muka langsung, namun hal itu sangatlah sulit dilakukan dalam masa pandemic seperti sekarang ini.

Cara yang paling tepat adalah dengan menggunakan zoom meeting sebagai media pembelajaran. Hal ini sejalan dengan pendapat Zhang dkk. (2006) menemukan bahwa video interaktif berpengaruh positif terhadap hasil belajar dan kepuasan siswa terhadap pembelajaran-el. Penelitian tersebut melibatkan empat kondisi pembelajaran yang berbeda. Tiga kondisi pertama merupakan pembelajaran-el dengan video interaktif, video noninteraktif, dan tanpa video. Pengaturan terakhir merupakan pembelajaran konvensional di kelas. Hasil dari penelitian ini menunjukkan bahwa siswa yang belajar dalam lingkungan pembelajaran-el dengan video interaktif di dalamnya memperoleh hasil belajar yang lebih baik dan kepuasan belajar yang lebih tinggi dibandingkan dengan tiga pengaturan belajar lainnya.

Berdasarkan pemaparan di atas, dapat disimpulkan bahwa penggunaan video interaktif dengan zoom dalam pembelajaran materi persamaan pecahan 
mata uang dapat digunakan sebagai alternatif dalam kegiatan pembelajaran jarak jauh, khususnya dalam pembelajaran matematika. Hal ini dikarenakan video interaktif mampu meningkatkan kemampuan mengingat siswa, intensitas kegiatan belajar siswa, dan juga interaksi siswa dengan materi pembelajaran. Selain itu, video interaktif juga membantu siswa lebih fokus terhadap aspek penting dalam video dan membantu siswa dalam meningkatkan kepercayaan diri dalam belajar.

Dalam kegiatan belajar mengajar antara guru dan siswa selama masa pandemi lebih banyak menggunakan pembelajaran daring, bahkan mungkin kedepannya pembelajaran jarak jauh menjadi salah satu model pembelajaran yang bisa dilakukan di sekolah. Dengan berkembangnya teknologi hadir aplikasi bernama zoom cloud meeting yang dapat melaksanakan kegiatan meeting atau diskusi secara bersama seperti bertatap muka secara langsung tanpa harus bertemu secara fisik. Aplikasi untuk videoconference dengan mudah dapat di instal pada perangkat PC, Laptop dan Mobile.

"Zoom Meeting" begitulah sebutannya, aplikasi ini sangat cocok sekali untuk melakukan video conference, dengan ringanya bandwidth yang digunakan, tidak ada iklan di aplikasi tersebut, serta tidak terlalu banyak memakan resource memory jika dijalankan di smartphone atau PC.

Pendidikan adalah usaha sadar dan terencana untuk mewujudkan suasana belajar dan proses pembelajaran agar peserta didik secara aktif mengembangkan potensi dirinya untuk memiliki kekuatan spiritual keagamaan, pengendalian diri, kepribadian, kecerdasan, akhlak mulia, serta keterampilan yang diperlukan dirinya dan masyarakat, bangsa dan Negara. (UU SISDIKNAS No.20 Tahun 2003)

Penelitian tentang penggunaan zoom pernah dipublikasikan oleh Jurnal Inovasi Penelitian dengan judul Sosialisasi Penggunaan Aplikasi Zoom Meeting dan Google Classroom Pada Guru Di SD N 17 Mata Air Padang Selatan yang ditulis oleh Suhery, Trimardi Jaya, dan Putra Jasmalinda

Berdasarkan uraian masalah di atas maka rumusan masalahnya adalah sebagai berikut:

1. Bagaimana pembelajaran jarak jauh dengan menggunakan zoom pada materi persamaan pecahan mata uang?

2. Apakah efektif pembelajaran jarak jauh dengan menggunakan zoom pada materi persamaan pecahan mata uang?

Berdasarkan rumusan masalah di atasa makan tujuan dilaksanakannya penelitian adalah sebagai berikut:

1. Mengetahui pembelajaran jarak jauh dengan menggunakan zoom pada materi persamaan pecahan mata uang.

2. Menegetahui efektif pembelajaran jarak jauh dengan menggunakan zoom pada materi persamaan pecahan mata uang.

\section{METODE}

Metode penelitian yang digunakan oleh penulis adalah observasi. Observasi adalah suatu cara pengumpulan data dengan pengamatan langsung dan pencatatan secara sistematis terhadap obyek yang akan diteliti. Observasi dilakukan oleh peneliti dengan cara pengamatan dan pencatatan mengenai pelaksanaan pembelajaran di kelas, baik kelas nyata ataupun kelas maya.

Penelitian ini merupakan jenis penelitian PTK. Dilaksanakan dengan menggunakan dua siklus dengan tujuan untuk mengetahui tingkat keberhasilan 
penggunaan media zoom jika dibandingkan dengan media yang lain. Pada siklus pertama dilaksanakan pada tanggal 16 November 2020 dengan menggunakan media WA Grup pada siklus kedua dilaksanakan pada tanggal 23 November 2020 dengan menggunakan zoom. Teknik pengumpulan data dengan cara siswa mengumpulkan tugas yang diberikan oleh guru. Lalu guru menilainya.

\section{HASIL DAN PEMBAHASAN}

Penelitian tindakan dilakukan dalam beberapa siklus sesuai dengan kebutuhan. Dimana pada masing-masing siklus diberikan perlakuan yang sama (tentang alur kegiatan yang sama) dan membahas satu pokok bahasan yang diakhiri dengan evaluasi pada akhir masing-masing siklus.

\section{a. Prasiklus}

Pada tahap ini peneliti melakukan observasi dikelas terkait permasalahan yang muncul saat pembelajaran tematik, peneliti melakukan wawancara kepada guru kelas dan sebagian siswa tentang bagaimana guru saat menjelaskan pembelajaran, aktivitas siswa, model pembelajaran yang digunakan dan tentang hasil belajar siswa saat pembelajaran tematik.

\section{b. Siklus I}

Penelitian pada siklus I ini dilakukan dengan melakukan tindakan berupa:

1) Perencanaan (Planning)

Pada tahap perencanaan, peneliti menyusun rencana kegiatan yang akan dilakukan sebelum melakukan tindakan pada siklus I, berikut ini merupakan kegiatan yang dilakukan penelitian:

a) Membuat Rencana Pelaksanaan Pembelajaran (RPP) siklus I yang difokuskan pada perencanaan langkah-langkah perbaikan atau skenario tindakan yang diharapkan dapat meningkatkan hasil belajar belajar pada mata pelajaran matematika. Dalam rencana perbaikan pembelajaran ini peneliti menerapkan media pembelajaran WA Grup

b) Menyiapkan instrumen pengumpulkan data : (1) Lembar observasi guru; (b) Lembar observasi siswa; (c) Menentukan kriteria keberhasilan dalam penelitian ini

c) Presentase ketuntasan siswa yang mencapai KKM sebesar $\geq 75 \%$. Ratarata hasil belajar siswa terhadap pembelajaran tematik subtema Tugasku sehari-hari di Rumah mencapai $\geq 70$. Skor aktivitas guru mencapai $\geq$ 80.Skor aktivitas siswa mencapai $\geq 80$.

2) Pelaksanaan (Acting)

Tahap ini penelitian (guru) melaksanaan pada pembelajaran pada mata pelajaran matematika di dengan media WA Grup. Kegiatan pembelajaran yang dilakukan mengacu Rencana Pelaksanaan Pembelajaran (RPP) yang disusun untuk siklus I. adapun rincian rencanapelaksanaan pembelajarannya meliputi kegiatan awal, kegiatan inti, dan kegiatan penutup.

3) Pengamatan (Observing)

Pada tahap ini peneliti melakukan pengamatan terhadap proses pembelajaran matematika di kelas II SD Negeri Bukateja 01Kecamatan Balapulang Kabupaten Tegal. Hal yang dilakukan peneliti adalah sebagai berikut. Mengamati semua proses pembelajaran dan mencatat semua masalah atau kekurangan pada pembelajaran tematik subtema Tugasku sehari-hari di Rumah. Mengisi data yang diperlukan dalam penelitian, seperti mengisi lembar observasi yang meliputi lembar observasi siswa, dan lembar observasi guru. 
4) Refleksi (Reflecting)

Pada tahap ini yang harus dilakukan adalah menganalisis hasil observasi yang telah dilaksanakan pada siklus I. Peneliti mengevaluasi hasil observasi dan menganalisis hasil pembelajaran, yang mana dapat diketahui apakah kegiatan yang dikatakan pada siklus I dapat meningkatkan hasil belajar siswa kelas II SD Negeri Bukateja 01 Kecamatan Balapulang Kabupaten Tegaldalam pembelajaran tematik subtema Tugasku sehari-hari di Rumah. Peneliti juga dapat mencatat kelemahan-kelemahan proses pembelajaran pada siklus berikutnya sampai tujuan PTK tercapai.

Hasil pembelajaran materi persamaan pecahan mata uang pada

\section{c. Siklus II} dengan menggunakan media WA Grup ternyata hanya bisa mencapai 20\% siswa bisa mencapai KKM.

Kegiatan siklus II ini adalah kegiatan tindak lanjut dari hasil evaluasi siklus I, jika pada sikulus 1 menggunakan media pembelajaran WA Grup, maka pada sikuls dua menggunakan media zoom meeting. Cara menggunakan zoom Agar dapat menggunakan Zoom, kamu hanya perlu mendaftarkan diri secara gratis, baik melalui aplikasi di HP atau website, berikut caranya:

Di website:

1. Kunjungi zoom.us, lalu klik tombol Sign Up.zoom meeting

2. Isi kolom email dengan email aktifmu, lalu cek email dari Zoom di kotak masukmu.

3. Klik "Activate Account" hingga kembali diarahkan ke browser untuk membuat password baru.

4. Jika sudah mempunyai akun, kamu bisa memilih Sign In, lalu memasukkan email dan password yang kamu gunakan untuk mendaftar Zoom Meeting.

Di HP:

1. Buka aplikasi Zoom, lalu klik Sign Up.

2. Masukkan alamat email, nama depan, dan nama belakang yang ingin digunakan bagi pengguna lain. Jangan lupa untuk mencentang persetujuan Terms of Service. Setelah itu, klik Sign Up.

3. Zoom akan mengirimkan email ke alamat email yang kamu gunakan.

4. Klik "Activate Account" di email yang masuk dari Zoom.

5. Lalu kamu akan diminta untuk menentukan password untuk akun Zoom milikmu. Selesai.

6. Jika sudah punya akun, kamu bisa memilih Sign In, lalu memasukkan email dan password yang kamu gunakan untuk mendaftar Zoom Meeting.

Hasil pembelajaran pada siklus dua menunjukan hasil pembelajaran sejumlah $100 \%$ yang artinya semua siswa sudah berhasil.

\section{SIMPULAN}

Berdasarkan uraian di atas maka dapat disimpulkan bahwa pembelajaran dengan menggunakan zoom pada materi persamaan pecahan mata uang efektif karena bukan hanya menyampaikan materi saja. Tetapi juga bisa memberikan rekaman bagi otak siswa sehingga mudah dipahami.

\section{DAFTAR PUSTAKA}

Anurrahman. (2012). Belajar dan Pembelajaran. Bandung: Alfabeta. Anurrahman. (2012). Belajar dan Pembelajaran. Bandung: Alfabeta. 
Arikunto,Suharsimi. (2006). Prosedur Penelitian Suatu Pendekatan Praktik, Jakarta: PT Asdi Mahasatya.

Basrowi dan Suwandi. (2008). Prosedur Penelitian Tindakan Kelas, Bogor: Ghalia Indonesia.

Hamalik, Oemar. (2001). Proses Pembelajaran. Bandung: Bumi Aksara.

Ira Dwi, et.al. (2017). Penerapan Model Make a Match Untuk Meningkatkan HasilBelajar Matematika Materi Pecahan Pada Siswa Kelas IV SD Negeri Diwak, Jurnal Pendidikan Matematika Vol.5, No.3.

M.J. Longeveled. (n.d.). Retrieved from http://repository.unpas.ac.id/133 18/4/BAB\%20I\%20acc.pdf

McLeod Pearson. (2008). Sistem Informasi Manajemen. Jakarta.

Shely Cashman. (2007). Discovering Computer.

Suherly, dll. (2020). Sosialisasi Penggunaan Aplikasi Zoom Meeting Dan Google Classroom Pada Guru Di Sdn 17 Mata Air Padang Selatan. Padang Selatan: Jurnal Inovasi Penelitian

Undang - Undang SISDIKNAS No.20 Tahun 2003. 